\section{Perception of health/illness associated with gender roles displaced women located in Medellín, Colombia, 2013-2014}

\author{
Percepción de la salud/enfermedad, relacionadas \\ con los roles de género en mujeres desplazadas, \\ residentes en Medellín, Colombia, 2013-2014
}

Percepção de saúde/adoecimento associada a papéis de gêneros em mulheres em situação de deslocamento situadas em Medellín, Colômbia, 2013-2014

\author{
Isabel Cristina Posada-Zapata 1 \\ Isabel Cristina Orozco-Giraldo 1,2 \\ Abraham Mendoza-Rios 1 \\ Carolina Restrepo-Correa 1 \\ Sara María Cano-Bedoya 1
}

doi: 10.1590/0102-311X00088618

\begin{abstract}
The objective of this study is to describe the experience of displaced women in Medellin, Colombia, and how this circumstance has an impact on the roles and perceptions of health/illness. This was a qualitative study using symbolic interactionism. Instruments from the Grounded Theory methodology were used. The study population was composed of adult women who have been displaced for at least 1 year and who live in 3 settlements in the city of Medellin. The instruments for data collection were 15 semi-structured interviews, 6 focus groups, and 6 in-depth interviews. Coding, categorization and interpretation, and, lastly, theorizing were used for analysis. What women go through displacement affects the roles they play both in relation to their family - one of the most significant components of their lives -, and in the social/community and health/illness processes, turning them into people with high degrees of vulnerability and social marginalization. Women who have been displaced face multiple obstacles, losses, and transformations, leading to a decline in their physical and mental health.
\end{abstract}

Women's Health; Human Migration; Violence Against Women
Correspondence

I. C. Orozco-Giraldo

Universidad de Antioquia.

Cl. 62 \#52-59, Medellín / Antioquia - 050001, Colombia.

icristinaorozcogiraldo@gmail.com

1 Universidad de Antioquia, Medellin, Colombia.

2 Universidad Católica Luis Amigó, Medellín, Colombia. 


\section{Introduction}

In Colombia and in the rest of the world, conflicts, wars, persecution, and forced displacement have been devastating situations for people, families, communities, and countries. These circumstances have separated people from their lands, economic assets, ties to their surroundings and, in many instances, their families. Moreover, numerous violations of Human Rights and International Humanitarian Law are found, including homicides; enforced disappearances; forced displacement; genderbased violence, sexual violence; kidnapping; land dispossession; anti-personnel mines; and torture 1,2.

Enforced displacement and the number of armed conflicts worldwide has reached dramatic levels. According to reports by the United Nations High Commissioner for Refugees (UNHCR), in 2014, there were 59.5 million forcibly displaced people. In Colombia, 5,185,406 people were officially registered as internally displaced in 2013, with a disproportionate impact on the Afro-Colombian population and indigenous communities. Colombia ranks second in the world in the number of internally displaced people, behind Syria 2,3,4.

Enforced displacement and armed conflicts have humanitarian consequences that are accentuated in highly vulnerable social groups, including ethnic minorities, children, older adults, disabled people, and women. Given this context, nobody is exempt from violence, but women and girls are particularly affected because of their status in society. Sexual and gender-based violence (including rape, forced pregnancy or forced abortion, human trafficking, sexual slavery, and the intentional exposure to sexually transmitted infections like HIV/AIDS) is one of the characteristics that define contemporary armed conflicts. In Colombia, a report by the Unit for Attention and Reparation of Victims shows that $83 \%$ of the victimization acts during the armed conflict were committed against women 5 . Similarly, women experience separation and loss of families, physical and economic insecurity, death, forced displacement, kidnapping, and forced recruitment $1,2,5$.

Therefore, it is evident that the experience of displacement drastically impacts the lives of the women who experience it, and displacement, in most cases, tends to be devastating. This phenomenon can be exemplified by women who move to urban areas, doing so under very precarious conditions, without access to basic services. Similarly, they do not have money for housing or food, risking being victims of sexual exploitation. Furthermore, given the absence of male relatives present, especially after an armed conflict, women are forced to assume nontraditional roles, facing discrimination and prejudice as a result 1 .

We must highlight that despite these obstacles, women who have been displaced demonstrate great resilience, ingenuity, and courage in adapting and overcoming these difficulties. These women have often been victims of serious human rights violations, but simultaneously, they are strong survivors; and with active participation and empowerment, they have managed to become leaders in supporting and rebuilding their families and the social fabric of their communities 1.

This situation motivated the team in the area of Research on Sexual and Reproductive Health of the Mental Health Research Group at the National School of Public Health to conduct a study with the objective of describing the experience of displaced women in Medellin, Colombia, and how this situation affects the roles and perception of health/illness.

\section{Methods}

This study was conducted with a qualitative and holistic focus because it sought to analyze and interpret in the broadest manner the different meanings of the experiences of displaced women and how these incidents determine the role of women. Using symbolic interactionism as the theoretical basis, the meanings of the acts and words for this group of people were explored, in addition to how these meanings were built through interactions with others, how these meanings were grouped, and, lastly, how these meanings were used to form an ensemble of meanings around the speeches of these women 6 . This type of methodology allows the conclusions of the studied population to surface, and may lead to conclusions that are not in line with those found in the literature.

G. H. Mead's symbolic interactionism was spread mainly by Ellsworth Faris and Herbert Blumber in the School of Chicago (USA), but it was the latter who coined such a term. For Blum- 
ber, Erving Goffman is considered the founder of the interaction order as a legitimate domain of sociological study 7 .

The core interest of symbolic interactionists lies in the influence of meanings and symbols on human action and interaction. Meanings and symbols assign distinctive characteristics to social actions (which implies a single actor) and social interactions (two or more actors involved in a mutual social action). Social action is that in which the individual "acts with others in mind". From this point of view, the social actor constructs symbolic realities as long as his reflective capacity allows him. In the process of social interaction people communicate symbolic meanings to one or more people involved in such operation. The others interpret these symbols and guide their response based on their interpretation of the situation; thus, in social interaction actors undertake a process of mutual influence 8 .

The instruments proposed by the Grounded Theory methodology were employed to conduct this study. Grounded Theory defines itself as an explanatory model derived from systematically collected and analyzed data through a research process. In this method, data collection, analysis, and the theory that emerges from them are closely interrelated 9 . Subsequently, the concepts tied to the experiences of these women were interpreted, and the data were categorized.

Medellín has received entire families that have escaped the fighting and threats from official and insurgent armed forces. Because the city never ceased to receive people seeking safety for their families, the city's hillsides became densely populated, and communities were built in the settlements and quickly began a process of organization and struggle for their rights and for social inclusion as citizens.

The settlement of La Cruz is located in the northeast end of Medellín, forming part of district 3 (Manrique); most of its population comprises displaced people. The social conditions of this population are of high vulnerability (in housing, limited access to public services, education, health, food, mobility, and few entry points), and their employment is concentrated in construction, various trades, and the informal sector. Unemployment is also a constant for the population, which makes it difficult to counter the social issues that it faces 10 .

Mano de Dios was a settlement that was close to downtown Medellín, and this area also received displaced families, mostly Afro-descendants who migrated from their hometowns because of the armed conflict. In 2003, a fire occurred in this settlement, affecting many residents. Consequently, these families suffered internal displacement within the city, which means double displacement for those who had already been displaced. These people were relocated to the Nuevo Amanecer neighborhood, located in the township of Belén Altavista. This neighborhood comprises approximately 3,600 people who also experience precarious social conditions, including environmental pollution from the nearby brickmaking industry, scarce employment opportunities, limited access to healthcare, discrimination, and violence.

The criteria for inclusion used to select the population were: women who were of legal age (over 18 years old), who had been displaced for at least 1 year, and who lived in one of the 3 selected settlements at the time of the study. In total, 15 initial interviews, 6 focus groups, and 6 in-depth interviews were conducted, with the participation of 49 women in total.

Initially, community leaders from the three settlements were contacted so researchers could get to know the community and invite women who met the inclusion criteria to participate in the research. In this awareness-raising phase, the research team went to each settlement to present the project and the women, voluntarily, gave their contact information to build a database of potential participants.

To conduct the first data collection phase, 15 participants were chosen, to whom the first instrument was applied: a semi-structured interview.

Following, 36 women were contacted, they would compose the six focus groups for the second phase of data collection. Women who stood out in the first phase for their communication and expression skills and women who had not participated were considered for this phase.

Participating women gave positive responses in the 3 phases, thus facilitating the research process.

The initial interviews broached issues such as the experience of displacement, the relationship between the roles that women have and their health, and the perception of their families. In the focus groups, the subjects of how women contributed to their own health care and the care of their families, how their own health care had changed after displacement, and the connections between social 
conditions and illness were discussed. Lastly, the in-depth interviews were conducted to test the hypotheses that were developed over the study period.

To select participants, theoretical sampling was adopted, which entailed choosing the population according to the needs of the reference categories. In other words, the women were initially selected with the objective of having a group with different sociodemographic characteristics that would provide information from various perspectives. For the other data collection stages, the women chosen were, based on the results obtained, those who could nourish the study due to their knowledge of the community or their leadership.

Two types of information sources were considered: primary sources, comprising the speeches of the participants; and secondary sources, comprising a review of official documents, literature, and other studies.

The analysis plan consisted of three basic procedures: first, coding, by means of a line-by-line analysis of the interviews with participants. This procedure began with open coding, progressed to an analytic coding that searched for relationships, and finally a selective coding that sought to strengthen the interpretation. This procedure was followed by categorization, in which a subsequent grouping into descriptive, analytical, and interpretive clusters was performed. Lastly, theorizing was performed, i.e., the construction of an explanatory model that would respond to the research question 9 .

After the analysis, a validation of the findings was performed by sharing them with the wider community of settlements, with the participants recognizing the validity of the presented results.

To perform this study, the principles established in the Declaration of Helsinki, which urge researchers to guarantee the protection of the life, heath, dignity, integrity, self-determination, privacy, and confidentiality of the personal information of the subject population, were considered 11. Similarly, Resolution 8,430 12 of the Colombian Ministry of Health, issued in 1993, which regulates research on human beings, was also considered. Accordingly, this project was categorized as greater than minimal risk, which is why the possible psycho-social risks arising from the discourse of the participants were always considered. Furthermore, informed consent forms were applied to all participants. Given these considerations, the endorsement of the Ethics Research Committee of the National School of Public Health of the University of Antioquia was obtained.

\section{Sociodemographic characteristics of the participants}

\section{- Age}

The mean age of the 49 participating women was 37.7 years. At the time of the investigation, the youngest woman was 18 years old and the oldest was 70 years old.

\section{- Place of origin}

Women in displacement who participated in the research came from different places, both from the department of Antioquia and from other departments and municipalities of Colombia, among participants, most women were from the department of Chocó (20 women, equivalent to 40\%), specifically from Dabeiba (5 women, 10.9\%), Urabá (3 women, 5.4\%), Apartadó (2 women , 3.6\%), San Luis (2 women, 3.6\%), Bello Oriente neighborhood (2 women, 3.6\%), Córdoba ( 2 women, 3.6\%). The remaining $29.3 \%$ of women came from other departments and municipalities.

\section{- Schooling}

Among the participants, $26.5 \%$ had completed high school (13 women). $24.48 \%$ had not completed primary education: 3 women reached third grade (6.12\%), 5 women, second grade (10.20\%), 2 women, fourth grade (4.08\%), and 2 women, first grade (4.08\%). 12.24\% of the participants completed primary education (6 women). $70.4 \%$ of the participating women did not complete secondary education: 4 women reached eighth grade (8.16\%), 3 women, tenth grade (56.12\%), 2 women, ninth grade (4.08\%), and 1 woman reached seventh grade (2.04\%). 8.16\% of women reached the technical level (4 women) and 1 woman was illiterate $(2.04 \%)$. 


\section{- Number of children}

The mean number of children of the participating women was 3.75 children. Four women had no children (8.16\%). Two was the lowest number of children and 10 the highest.

\section{- Current place of residence}

In 2003, Mano de Dios became Nuevo Amanecer due to a fire that forced its inhabitants to occupy another settlement. This explains why the participating women belong only to two settlements, and not to three as had been proposed in the project, since Nuevo Amanecer has existed since 2006 (8 years before the publishing of this article), and includes women from Mano de Dios. Therefore, 23 women (46.9\%) lived in Mano de Dios, now Nuevo Amanecer, and 12 women lived in Nuevo Amanecer more than 8 years ago (24.48\%) and, 14 women live in La Cruz (28.57\%).

\section{- Marital status}

At the time of the investigation, there were 32 single women (65.3\%), 7 living in cohabitation (14.2\%), 4 widows (8.16\%), 4 others did not respond (8.16\%) and 2 more divorced (4.08\%).

\section{- Ethnicity}

Among participants, 20 were Afro-descendent (40.81\%), 13 responded that they did not belong to any ethnic group (26.5\%), 12 did not respond (24.48\%) and 4 identified themselves as mestizo (8.16\%).

\section{Results and discussion}

The Latin American region shows the highest rates of inequality in the world due to economic injustice and inequalities in health that have long been distinctive features. The reduction of poverty persists as one of the most difficult problems to solve, paired to a growing segmentation of health services 13 .

Likewise, reports show the use of sexual violence as a weapon of war in internal conflicts in this region. In the specific case of Colombia, its various territories have been severely affected by armed conflicts. Women make up a sector of the civilian population whom have lived its consequences in a different manner, as they are the target of particular violence that tends to be exacerbated amid a conflict. The social unrest caused by situations of armed confrontation create scenarios conducive to the practice of different types of violence 14 .

On the other hand, the social determinants of health, according to the World Health Organization (WHO), are defined as the circumstances in which people are born, grow up, live, work and age, including the health system. These circumstances are the result of the distribution of money, power and resources worldwide, nationally and locally, and depend on the policies implemented 15.

Income, education, age, ethnicity, sexual orientation, and place of residence are important determinants. When interrelated with gender inequality, these factors can aggravate discrimination, health risks, and lack of access to resources needed to achieve positive health outcomes 16 .

Social vulnerability is defined as the capacity of households and people to face a crisis in terms of factors of basic survival, considering the available resources, e.g., housing, health, education, income, and public social services 17 . To these issues are added categories such as marginalization, discrimination, exclusion, and inequality. These issues affect population groups experiencing social crisis, as is the case with women who have been displaced 18 .

Despite the different situations of vulnerability that displaced women, the family sphere is one of the components that has the most influence and importance in the lives of women. A 2009 study in Bogotá highlights that displaced women still hold deeply entrenched notions about family. In total, $50.6 \%$ of displaced women believe in the nuclear family and accept it as the only option 18 . 
"For me, family means a lot: love, freedom. It is something that you have as a displaced person. It is the love for your family, that could save itself, that managed to escape an attack, violence. In other words, in this case, there is more family unity and more love in the family" (FG3C106).

In addition to what has been stated, family fulfills multiple functions, especially those related to the satisfaction of material and emotional needs. The family has been responsible for the quality of life of the people who constitute it 18 . During their lives, the families of displaced women had to overcome many difficult situations that compromise their structure, such as losing a family member due to violence, which creates incurable pain.

"When you lose someone, you feel that half of what you have inside is ripped from you [crying]. And when that something is ripped from you, you feel that the pain reaches, like, the deepest place that a human being can feel pain. That is, to feel pain is not to have your arm ripped off, it is to have that other half that helps you live every day taken from you, that half that makes up that family that carries you forward" (ID1C91).

"They've hurt us a lot, not just us, many people around us, they never think of the damage they're doing, because they don't know, they don't know what they're doing, leaving a child orphaned, without a dad, not knowing what may happen later, but that's life and this is the way to face it" (EP4C45).

Nevertheless, some displaced women state that the death of a family member due to displacement has created more unity within the household, given that the family is the site and space where the shared values and assumptions about how to be and act in society are founded. This is supported by the opinion of a displaced woman who stated that:

"The death of my mother, we each went on our own, that is, we separated. But when they killed an uncle, our grandparents came, sat down with us, and told us that after the death of my mother we had to be closer, to realize that the only women left were the two of us and that they could not abandon us" (FG2C132).

Nowadays, "family" involves multiple forms of organization, and one of these typologies is the single-parent family. Among the participants, 20.2\% have the "woman with her children" as a notion of family. There several causes for accepting this typology: women who were abandoned, who were widowed, or who divorced, because the internal conflict experienced in the country led to the murder, disappearance, or distancing of their husbands or partners; in very few cases, being alone with her children was the personal decision of the woman 18. Thus, this reason becomes the reason to live for displaced women. To demonstrate this argument, a participant states:

"I am alive because I have a daughter who helped me. This 9-year-old girl told me to get up, that life goes on, that I was alive, and that I had many things to fight for, such as my children" (ID1C93).

Women who perform as both mother and father is an increasingly common pattern in underdeveloped countries. Women thus assume leadership roles that were previously made invisible because they become responsible for the survival of the family unit and the procurement of housing, health, and food while facing maladaptation to the urban context, social discrimination, and disorientation 19

Nevertheless, it is not only because of the physical loss - death, forced recruitment, kidnapping, the enforced disappearance of their spouse or partner, abandonment, or separation - that women must assume this new role. In many cases, the men who are present in the households are not willing to provide for the necessities of the family group 20 . One of the interviewed women stated that:

"See, it was up to me. I would go to work, and when I returned, because that miserable man didn't even do the dishes, I had to come home to do the dishes myself. I would also have to come home and cook for him, leave him prepared food so that he would eat when I was working" (FG6C206).

"I'm telling you, I confess, I live, where I live, I live with a man, but he loves my children and takes care of them, but I don't depend on him, no, rather he depends on me" (E2C52).

Most displaced women are from rural areas with social structures that are characterized by a patriarchal conception of family, in which the man gives orders and the woman obeys 20. Furthermore, life before displacement was characterized by having food that came from the land, dedicating most time to fieldwork, and maintaining strong family ties with shared projects. In the economic sphere, there were resources to guarantee security, which allowed women to construct a specific life plan that would respond to their needs and wishes, such as being a married woman who dedicated herself to raising her children and doing housework, among other things. Echoing the above, one of the interviewed women in the La Cruz settlement stated:

"By contrast, when I was in the countryside, I was happy. I did not have the life that I have now. With the first children I had, those kids never lacked anything. We had good milk, fresh cheese, beans, plantains, cassava. I did 
not lack anything. If I wanted meat, I would kill a chicken, or two if there were many family members, and eat it. Or every 20 days, every month, we killed a pig and like that, or if multiple farmers came together, we would kill a steer, and we would share it between various people. One lived this way, happy" (I2C92).

Displacement is a dynamic of mobility that includes individual, family, and community processes. In Medellín specifically, the armed conflict, violence, and the constant violation of the population's human rights are the primary causes of this issue. This proposition is supported by the opinion of a woman who stated:

"When my son decided to come as well, because he came with me when the displacement happened but left again for my mother's house. And when he came, he was overloaded with stress again because he did not adjust, and I too became fearful since, here in Medellin, there is so much violence" (I4C24).

When women are displaced from their hometowns and arrive in urban settings, they must forego the activities that they used to perform to look for a job or a method of subsistence that would allow them to generate income to support their family. Generally, these activities are informal, with the women, very often dedicating themselves to begging; domestic work such as cleaning, cooking, washing, and ironing clothes; street vending; and other activities. These skills are useful for survival and allow women greater possibilities to meet their responsibilities as providers for the family unit 21 .

In this context, displaced women start to give greater importance to education because they view it as an indispensable tool for better living conditions and for building an ideal future for themselves and their families 22 .

Nevertheless, some women who have been displaced observe the possibility of disintegration or harm to the family as a result of continuing their studies, believing that if they are away, there is no other person who can act as the head of the household. In turn, this idea is influenced by a previously received patriarchal education in which the woman must remain at home and the family unity depends on her. This idea is supported by a participant:

"I look at my other friends, they work and study, and their children get lost in the streets. I prefer for my children not to become lost and not to study. I'll sacrifice my studies as long as my children do not get lost in the streets because those children that I have seen are planning on stealing and getting their hands on a gun. So, I see that that isn't good" (I13C43-44).

Therefore, displaced women are characterized by the deferral of some of their projects, thinking that these will negatively impact the well-being of their families. Furthermore, after the experience of displacement, women transform their personality in diverse ways according to the situations that they may face. Among these, we found the perception of vulnerability, fear, and the desire for selfimprovement, and we found a permanent desire to "help others" as a guiding feature for their actions, in terms of both labor and education. This argument is reflected in the following statement:

"Because I have had the experience. If I have 10,000 pesos... for example, and there is a person that has nothing to eat, no? I divide it up, I buy, and it is possible that I'll bring half of what I bought to that person so that they can meet their need" (I13C92).

Some women constantly perceive the possibility of being harmed again and becoming a target; they feel distrust, a lack of support, and the possibility that they or a loved one will be harmed or even lose his or her life.

"That is to say, you will always be, you go out... for example, we are here in this, in this moment, we go out downtown, we are walking around, and you always remember what happened to you, or I question what if someone is following me, or what if, all of a sudden, the person who, the person who was going to kill me is on this bus, and they are around here" (FG6C312).

In the personal/individual sphere, displaced women show feelings of insecurity with the possibility of losing everything again at any moment. If I can lose everything in a minute, why rebuild? Why organize ourselves again? 23.

"Yes, because I do not trust anyone anymore. I don't like it when people go to my house. Why? To see how I live? In that case, no! I don't like it. If I do not have my mother, I do not have anyone, I'm alone. I do not like anyone going to my house precisely because of the same, because it is ahhg! How scary, a more serious problem if, all of a sudden, they make you leave your house or something like that. To me, that seems worse" (ID5C13).

Lastly, the experience of displacement causes the relationship with social/community groups to move in two directions. One is the loss of faith, with feelings of mistrust and isolation. From the other perspective, one finds organized empowerment, established to combat threats and to endure the 
everyday struggles, allowing the subject to face transformations, meet needs, maintain future plans, and defend rights.

Given this discussion, it can be concluded that gender is a constitutive element of social relationships based on the differences defining each sex and is also a primary form of significant power relations 24. The experience of displacement determines the role of women, given that it generates vulnerability in different contexts, such as in employment and education. Furthermore, through displacement, women take on new roles in their household because of the death of a loved one, such as a partner, whether due to being widowed or via separation. However, these experiences also create more love for the family circle and more of a sense of community or desire to "help others".

\section{Conclusions}

The social problem of forced displacement and armed conflicts in Colombia is an issue that has left indelible marks on millions of victims, breaking down the individual, family, and community stability of the persons and families affected. Most women face multiple obstacles, losses, and transformations because of the dismantling of structures after displacement, thereby generating a decline in their physical and mental health.

This study has made it possible to show that the family is one of the most important components in the lives of the participating women. The family is considered the space that guarantees survival and the management of solutions, from the emotional sphere to the economic sphere.

It is also important to reiterate that the experience of displacement forces most women to take on new roles. These entail a greater burden and responsibility in their lives because they must respond to the need to survive, face a completely unknown environment, become the head of the household because of the abandonment or death of their partners, look after the growth and protection of their children, economically sustain their household, rebuild their families given the family fragmentation caused by displacement, and actively participate in peace-building processes at community level.

The family members of displaced women must support them because they are taking on many roles that lead to high levels of stress. Such increased support would help to improve their health and would contribute to an adequate family environment. Therefore, the recommendation to government agencies is to create accompaniment programs for family members so they can identify the importance of teamwork and be made aware of the responsibilities that exist in the family environment.

We must note that when compared to white women, more Afro-descendant women have always worked outside their homes. The enormous significance that labor has in the lives of Afro-descendant women follows a pattern established during the first days of slavery; labor eclipses any other aspect of women's existence 25 .

In conclusion and based on the points raised over the article, we can affirm that the experience of displacement in women turns them into people with high levels of social vulnerability, which, as a consequence, leads to marginalization; unmet basic needs, including housing, health, education, diet, and income; insufficient public services; discrimination; and other problems, creating the large belts of poverty for these people because of the lack of opportunities in receiving cities. 


\section{Contributors}

All authors contributed equally in the production of the article.

\section{Additional informations}

ORCID: Isabel Cristina Posada-Zapata (0000-00034953-6490); Isabel Cristina Orozco-Giraldo (00000002-2676-045X); Abraham Mendoza-Rios (00000002-9869-4543); Carolina Restrepo-Correa (0000-0002-2842-090X); Sara María Cano-Bedoya (0000-0002-6241-0334).

\section{Acknowledgments}

The authors thank the CODI 2013-2014 Sustainability Strategy at the University of Antioquia.

\section{References}

1. The UN Refugee Agency. Manual del ACNUR para la Protección de Mujeres y Niñas. http:// www.acnur.org/t3/fileadmin/scripts/doc. php? file $=\mathrm{t} 3 /$ fileadmin $/$ Documentos $/$ Publica ciones/2009/7137 (accessed on 23/Apr/2018).

2. Carrillo A. Desplazamiento forzado y violencia sexual basada en género. https://www. humanitarianresponse.info/sites/www.huma nitarianresponse.info/files/documents/files/ Buenaventura\%2C\%20colombia\%20realida des\%20Brutales\%20Sept\%202014.pdf (accessed on 23/Apr/2018).

3. The UN Refugee Agency. Tendencias globales. Desplazamiento forzado en 2014. http:// www.acnur.org/t3/fileadmin/scripts/doc. php? file $=$ t $3 /$ fileadmin $/$ Documentos $/$ Publi caciones/2015/10072 (accessed on 23/Apr/ 2018).

4. Internal Displacement Monitoring Center. El desplazamiento continúa a pesar de esperanzas de paz. http://www.acnur.org/t3/uploads/ media/2875_IDMC_Colombia_16ene2014. pdf?view=1 (accessed on 23/Apr/2018).

5. Unidad para la Atención y Reparación Integral a las Víctimas. Informe delitos contra la integridad y la libertad sexual de las mujeres en el marco del conflicto colombiano. https:// rni.unidadvictimas.gov.co/sites/default/files/ Documentos/Informe-violencia-sexual-mu jeres-a-30-abril_2013.pdf(accessed on 23/Apr/ 2018).

6. Blumer H. El interaccionismo simbólico, perspectiva y método. Barcelona: Hora E Editores; 1981.

7. Universidad Católica Luis Amigó. Unidad II: interaccionismo simbólico y psicología social. http://virtual.funlam.edu.co/repositorio/sites/ default/files/repositorioarchivos/2010/02/ UNIDAD\%20II.330.pdf (accessed on 23/Apr/ 2018).

8. Mead G. Espíritu, persona y sociedad. Desde el punto de vista del conductismo social. Barcelona: Paidós Básica; 1982.

9. Strauss A, Corbin J. Bases de la investigación cualitativa técnicas y procedimientos para desarrollar la teoría fundamentada. Medellín: Editorial Universidad de Antioquia; 2002.

10. Ortiz A. Caracterización comuna 3 Manrique de la ciudad de Medellín. http://www. kavilando.org/images/stories/documen tos/CARACTERIZACION_COMUNA3_ MANRIQUE_O_G.pdf (accessed on 23/Apr/ 2018).

11. Asociación Médica Mundial. Declaración de Helsinki de la AMM. Principios éticos para las investigaciones médicas en seres humanos. http://www.isciii.es/ISCIII/es/contenidos/ $\mathrm{fd}$-investigacion/fd-evaluacion/fd-evaluacionetica-investigacion/Declaracion-Helsinki2013-Esp.pdf (accessed on 23/Apr/2018).

12. Ministerio de Salud de Colombia. Resolución no 008430 de 1993. http://www.minsalud.gov. $\mathrm{co} / \mathrm{sites} / \mathrm{rid} /$ Lists/BibliotecaDigital/RIDE/ DE/DIJ/RESOLUCION-8430-DE-1993.PDF (accessed on 23/Apr/2018). 
13. Carmona Z, Parra D. Determinantes sociales de la salud: un análisis desde el contexto colombiano. Salud UNINORTE 2015; 31: 608-20.

14. Marulanda N. La violencia sexual hacia mujeres en el marco de guerras y conflictos armados como expresión del patriarcado. Manifestaciones en el contexto colombiano [Monografía]. Medellín: Universidad de Antioquia; 2018.

15. World Health Organization. Closing the gap in a generation. Health equity through action on the social determinants of health. Final Report of the Commission on Social Determinants of Health. http://www.who.int/social_determi nants/final_report/csdh_finalreport_2008.pdf (accessed on 20/Sep/2018).

16. Organización Mundial de la Salud. Género. http://www.who.int/mediacentre/factsheets/ fs 403/es/ (accessed on 20/Sep/2018).

17. Romero C. Condiciones de vulnerabilidad social y acción colectiva de la población desplazada en Bogotá. Revista Colombiana de Sociología 2008; 30:21-46.

18. Pinilla M. Transformaciones y cambios percibidos por las mujeres a partir del desplazamiento, con relación a ellas mismas, y sus familias, y prácticas alternativas para responder a la subsistencia y la integración social [Masters Thesis]. Bogotá: Universidad Javeriana, Facultad de Ciencias Políticas y Relaciones Internacionales; 2009.
19. Vos Obeso R. Desplazamiento forzoso, género y derechos humanos. Razón y Palabra 2013; 16:342-354.

20. Gandulfo M. Roles de género y desplazamiento interno en Colombia. http://www.caei.com. ar/sites/default/files/al-15.pdf (accessed on 23/Apr/2018).

21. Luengo J. Teorías e instituciones contemporáneas de educación. http://avancelasta blas.es/psicologos-educacion/wp-content/ uploads/2016/12/1-EducacionConcepto.pdf (accessed on 23/Apr/2018).

22. Consultoría para el Desplazamiento Forzado y los Derechos Humanos, Fondo de las Naciones Unidas para la Infancia. Un país que huye: desplazamiento y violencia en una nación fragmentada. https://www.unicef.org/colombia/ pdf/codhes.pdf (accessed on 23/Apr/2018).

23. Arcila N. Cambios culturales y procesos comunicativos en mujeres afrocolombianas desplazadas por el conflicto social [Grade Thesis] Bogotá: Facultad de Comunicación y Lenguaje, Universidad Javeriana; 2008.

24. Scott J. Gender: a useful category of historical analysis. The American Historical Review 1986; 91:1053-75.

25. Davis A. Women, race and class. New York: Random House; 1981. 


\section{Resumen}

El objetivo de este estudio es describir la experiencia de las mujeres desplazadas en Medellín, Colombia, y cómo esta circunstancia tiene un impacto en los roles y percepciones en la metodología de salud/enfermedad: se realizó un estudio cualitativo, usando un interaccionismo simbólico. Se usaron herramientas basadas en la teoría de la metodología. La población estaba compuesta por mujeres adultas que se habian desplazado al menos 1 año y que viven en 3 asentamientos de la ciudad de Medellín. Las herramientas para la recolección de datos fueron 15 entrevistas semi-estructuradas, 6 grupos focales, y 6 entrevistas en profundidad. Se usaron para el análisis: codificación, categorización e interpretación, y, por último, la teorización. La experiencia de las mujeres respecto al desplazamiento las transformó en personas con altos grados de vulnerabilidad y marginalización social. Las mujeres que habian sido desplazadas enfrentaban múltiples obstáculos, pérdidas, y transformaciones, conduciéndolas al declive de su salud física y mental.

Salud de la Mujer; Migración Humana; Violencia Contra la Mujer

\section{Resumo}

O objetivo deste estudo foi descrever as experiências de mulheres em situação de deslocamento em Medellín, Colômbia, e como essa circunstância impacta seus papéis e percepções de saúdeladoecimento. Um estudo qualitativo foi realizado com base no interacionismo simbólico. Ferramentas da metodologia da teoria fundamentada foram usadas. A população era composta por mulheres adultas que estavam em situação de deslocamento há pelo menos 1 ano e que vivem em 3 assentamentos na cidade de Medellín. As ferramentas para a coleta de dados foram 15 entrevistas semi-estruturadas, 6 grupos focais e 6 entrevistas em profundidade. Codificação, categorização, interpretação e, finalmente, teorização foram usadas na análise. As experiências de deslocamento transformam as mulheres em pessoas com altos graus de vulnerabilidade e marginalização social. Mulheres que sofreram deslocamento enfrentam múltiplos obstáculos, perdas e transformações, levando a um declinio da saúde física e mental.

Saúde da Mulher; Migração Humana; Violência Contra a Mulher

Submitted on 04/May/2018

Final version resubmitted on 26/Sep/2018

Approved on 10/Oct/2018 
Posada-Zapata IC et al. 